\title{
About Some Aspects of Teaching Foreign Students in the Discipline "History of Medicine"
}

\author{
Nataliia Stytsiuk
}

\begin{abstract}
The objective of the research was to study the opinion of the first-year students of the Faculty of Foreign Citizens Training of the Ivano-Frankivsk National Medical University on some aspects of teaching the discipline "History of Medicine" to determine its areas for improvement.

Materials and methods. According to the author's program, a survey of 239 first-year students of IvanoFrankivsk National Medical University was conducted. They came from 10 countries, studiyng the specialty "Medicine". The results of research were mainly categorical (qualitative) data. Therefore, calculation of each factor rates per 100 respondents, standard errors of rates, and Chi-Square Test $\left(\chi^{2}\right)$ for comparing group differences have been used for statistical data analysis. The methods that have been mainly used are sociological, medical and statistical.

Results. The research found that the absolutely majority of students are from India (81.2\%) and about $59.0 \%$ of respondents profess Hinduism (59.0\%), but the shares of Muslims (21.3\%) and Christians (17.6\%) are also significant. There are $65.7 \%$ males vs. $34.3 \%$ of females among the respondents, which is obviously due to religious, cultural and national stereotypes of different countries $(p<0.001)$. The results of secondary education, with which foreign students entered university, were quite high. Almost $86.7 \%$ of surveyed first-year-students noted the high level of lectures on the subject "History of Medicine", pointing to their informativeness, accessibility, interesting and illustrative manner of presenting the material.

Conclusion. It was found that among foreign first-year students studying at the IFNMU, predominated males $(65.7 \%)$, aged from 19 to 21 years of $(62.3 \%)$, with a high basic level of secondary education (66.9\%). It was also shown that $91.7 \%$ of respondents are satisfied with the level of teaching "History of Medicine" and manner of presentation lecture material (86.7\%).
\end{abstract}

\section{Keywords}

History of Medicine, foreign students

Ivano-Frankivsk National Medical University, Ukraine

Corresponding author: natalusa12345@gmail.com

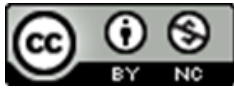

Copyright @Nataliia Stytsiuk, 2020

\section{Problem statement and analysis of the latest research}

Providing the population with quality medical care is the main task of medical education, which is provided by a high level of training of medical workers. Humans, their life and health are of the most important values of a modern doctor. At the same time, "quality medical care is impossible without changing the cultural paradigm and creating a new pro- fessional environment, which is self-reproducing and independent" [1]. The modern sphere of medical services in Ukraine needs a new type of doctors which are capable of innovative changes, comprehends the historical basis of transformation in medicine, professionally solves practical problems, and is highly motivated by successful activities and professional career development [2]. That is why it is difficult to separate medical education from 
humanitarian education in general and the development of historical thinking in particular, without international scientific cooperation in the field of health care etc. After all, medical science, as a branch of human activity and culture, in its content is a common asset of all mankind [3, 4].

Undoubtedly, the history of medicine as a science and as a subject in high school has a significant impact on the formation of worldview, morality, social position, increasing the level of general and professional culture among both Ukrainian and foreign medical students [5].

The objective of the research was to study the opinion of first-year students of the Faculty of Foreign Citizens Training of Ivano-Frankivsk National Medical University (IFNMU) on some aspects of teaching the discipline "History of Medicine" to determine its areas for improvement.

\section{Materials and Methods}

According to the author's program, a survey of 239 first-year students of Ivano-Frankivsk National Medical University was conducted. They came from 10 countries, studying the specialty "Medicine". The results of research were mainly categorical (qualitative) data. Therefore, calculation of each factor rates per 100 respondents, standard errors of rates, and Chi-Square Test $\left(\chi^{2}\right)$ for comparing group differences have been used for statistical data analysis [6]. The methods that have been mainly used are sociological, medical and statistical.

\section{Results and Discussion}

The research found that the absolute majority of students $(81.2 \%)$ are from India, the rest came to study from Egypt (5.4\%), Poland (5.0\%), Bulgaria and Nigeria (2.5\% for each), Ghana (1.3\%), Zambia $(0.8 \%)$ and Pakistan, Namibia and Germany $(0.4 \%$ for each).

Analyzing the answers of foreign students, it is important to take into account not only the country of origin, but also their religious affiliation. It is projected that the majority of respondents profess Hinduism (59.0\%), but the shares of Muslims (21.3\%) and Christians (17.6\%) are also significant.
This distribution may explain the fact that among the respondents there are $65.7 \%$ males vs. $34.3 \%$ of females, which is obviously due to religious, cultural and national stereotypes of different countries $(\mathrm{p}<0.001)$. Moreover, the age structure of first-year students was dominated by students aged 19 to $21(62.3 \%)$ and under $18(24.4 \%)$, which is significantly different from Ukrainian students studying in the first year of IFNMU.

It is noteworthy that the results of secondary education, with which foreign students entered our university, were quite high. Thus, more than half of the respondents $(66.9 \%)$ indicated that they graduated from school with only "excellent" and "good" grades, which is gratifying for us, because thorough basic knowledge is the key to successful further education in higher education.

The discipline "History of Medicine" is taught at the Department of Social Medicine and Public Health to first-year students in the first semester of the academic year. It is clear that teaching a subject to foreign students requires from the teachers proper training, high level of a foreign language, the ability to establish communications etc.

Analyzing the answers of respondents to the question "Are you satisfied with the level of teaching the history of medicine?" a third part of them $(36.8 \%)$ rated it as high, almost half $(54.9 \%)$ considered it as good and only $8.3 \%$ of respondents indicated that the level of teaching the discipline could be better $(\mathrm{p}<0.05)$.

The level of foreign language proficiency is one of the most important component for teachers in high school being also obviously essential for quality education of foreign students. Despite the fact that the teachers of the Department are constantly working to improve their language skills, we were still interested to learn how students assess the level of foreign language proficiency of their teachers. The results of the study showed that the vast majority of respondents $(89.8 \%)$ confirmed the high level of knowledge of teachers.

It is a great pleasure to note that $86.7 \%$ of surveyed first-year-students noted the high level of lectures on the subject "History of Medicine", pointing to their informativeness, accessibility, interesting 
and illustrative manner of presenting the material. This can be confirmed by the fact that there were almost no absences on lectures among foreign students. Quality preparation for seminars on the History of Medicine is an important part of studying the discipline. The material of lectures was mentioned as the main source of knowledge on the subject for $68.3 \%$ of respondents, $15.4 \%$ of students used to prepare for classes basic and additional educational literature recommended in the guidelines for students, another $16.3 \%$ of respondents combined all resources for learning, including various scientific online publications. At the same time, $34.7 \%$ of first-year-students expressed a desire to diversify and increase the number of textbooks on the History of Medicine at the university library.

The problem of teaching foreign students is the subject of study for scientiests around the world [7, $8,9]$.The actual issues of foreign students' education in Ukraine and the need for constant training of their features were studied by such national scientists as Ivakin S, Pluzhnikova T, Hasiuk N, Tytarenko S, Lysak O, Debych M, Stepanenko I. In particular, Stepanenko I et al. [10] quite rightly state and substantiate the fact that "attracting foreign students to study is one of the most important components of the internationalization of higher education", which is a very positive and appropriate phenomenon in the national educational system. Therefore, the disclosure of the characteristics of the quantitative and qualitative composition of foreign students is an important prerequisite for improving their training.

In order to improve the teaching of the discipline "History of Medicine" a variety of modern teaching methods, including showing thematic films and presentations, is used at the department. In addition, it is planned to hold some seminars on the basis of the Museum of the History of Medicine, which houses a lot of valuable medical books, rare exhibits and more.

In addition, interactive teaching methods also deserve attention, the active introduction of which into the educational process is a direct requirement of time, because "unlike active methods, interactive methods are focused on wider interaction of stu- dents not only with the teacher but also with each other, on dominance activities of students " [11]. Among them, such methods of interactive learning in groups as the method of "POPS-formula" (to check the results of individual work of students), the method of "world cafe" (to discuss problematic issues) may be useful in the course "History of Medicine", in particular, in seminars on the History of Medicine, in lectures such types as lecturesdiscussions also can be used.

\section{Conclusions}

It was found that among foreign first-year-students studying at the Ivano-Frankivsk National Medical University, predominate males $(65.7 \%)$, aged from 19 to 21 years $(62.3 \%)$, with a fairly high basic level of secondary education $(66.9 \%)$. It is shown that $91.7 \%$ of respondents are satisfied with the level of teaching "History of Medicine" and manner of presentation of lecture material $(86.7 \%)$. Identified wishes of foreign students should be taken into account in further teaching of the subject.

\section{Conflict of Interest}

The authors stated no conflict of interest.

\section{Financial Disclosure}

The authors declared no financial support.

\section{References}

[1] MOZ Ukrayiny. Stratehiya rozvytku medychnoyi osvity v Ukrayini [Elektronnyy resurs]. 2018 [cited 2020 Jan 04]. Available from: https://moz.gov.ua/uploads / 1/8475-medical_education_ analytics.pdf [in Ukrainian].

[2] Sokolova I. Medychna osvita Ukrayiny: svitovi tendentsiyi, yevropeyski oriyentyry i natsionalni priorytety. Nepererv. prof. osvita: teor. i prak. (seriya: ped. nauky). 2019; 2 (59): 7-15 [in Ukrainian]. 
[3] Pluzhnikova TV. Dosvid vykladannia istoriyi medytsyny inozemnym studentam na suchasnomu etapi rozvytku medychnoyi osvity v Ukrayini. In: Udoskonalennya yakosti pidgotovky likariv u suchasnyx umovax: materialy nauk.-prakt. konf. $\mathrm{z}$ mizhnar. uchastyu; 2016 March 24; Poltava. Poltava: 2016. p. 169-170. [Internet]. Available from : http://elib.umsa.edu.ua/jspui/ handle/umsa/9810 [in Ukrainian].

[4] Ivakin ST. Osoblyvosti organizaciyi vykladannia predmetiv $\mathrm{v}$ medychnykh navchalnykh zakladakh. Med. osvita. 2012; 3: 178-180 [in Ukrainian].

[5] Bilous VI, Bilous VV. Istoriya medytsyny i likuvalnoho mystetstva. Chernivtsi: IVCz " Misto". 2019; 284 p [in Ukrainian].

[6] Detsyk OZ. Metodychni pidkhody do uzahalnennia rezultativ naukovykh doslidzhen. Gal. Med. Journ. 2011; 18 (2): 5-8 [in Ukrainian].

[7] Lee, J, Ciftci A. Asian international students' socio-cultural adaptation: Influence of multicultural personality, assertiveness, academic self-efficacy, and social support. Int J Intercult Relat. 2014; 38: 97105. DOI: https://doi.org/10.1016/ j.ijintrel.2013.08.009

[8] UKEssays. (November 2018). A look at Problems faced by international students in UK [Internet]. 2018 Nov [cited 2020 Jun 18]. Available from https: / / www. ukessays. $\mathrm{com} /$

[9] Gatwiri G. The Influence of Language Difficulties on the Wellbeing of International Students: An Interpretive Phenomenological Analysis. Inquiries Journal/Student Pulse [Internet]. 2015 [cited 2020 Jun 20]; 7 (05). Available from http: / / www . inquiries journal. com/a? id=1042

[10] Stepanenko I, Debych M. Navchannia inozemnykh studentiv v Ukrayini: stan problemy, per- spektyvy. Vyshcha osvita Ukrayiny. 2017; 4: 48-55 [in Ukrainian].

[11] Bashkir OI. Aktyvni i interaktyvni metody navchannia u vyshchiy shkoli. Pedahohika ta psykholohiya. 2018; 60: 33-44 [in Ukrainian].

Received: $2020-07-20$

Revised: $2020-08-02$

Accepted: $2020-08-05$ 